\title{
Perilunate Lesions - Clinical and Radiological Results with a Minimum of 2 Years of Follow-up
}

\section{Lesiones Perilunares - Resultados Clínicos e Radiológicos con un Minimum de 2 años de Seguimiento}

\author{
Elisabete Ribeiro ${ }^{1}$ Nuno Oliveira ${ }^{1} \quad$ Juvenália Ribeiro $^{1}$ Pedro Varanda ${ }^{1}$ Luis Filipe Rodrigues ${ }^{1}$ \\ 1 Department of Orthopaedic Surgery and Trauma, Hospital de Braga, \\ Braga, Portugal \\ Rev Iberam Cir Mano 2021;49:13-18. \\ Address for correspondence Elisabete Fernanda Magalhães Ribeiro, \\ MD, Department of Orthopaedic Surgery and Trauma, Hospital de \\ Braga, R. de Sete Fontes, S. Victor, 4170-243, Braga, Portugal \\ (e-mail: elisabete.mgr@gmail.com).
}

\begin{abstract}
Keywords

- dislocation

- fracture-dislocation

- arthritis
\end{abstract}

Resumen
Perilunate injuries are complex and rare lesions with circumferential carpal bones, ligamentous and cartilage involvement. Despite optimal surgical treatment, poor prognosis is expected and usually gets worse over time. Our aim was to address clinical and radiological outcomes after 2 years of follow-up. Seven wrists were revised with average age of $35.59 \pm 14.01$ (range 21-56) years old and mean follow-up of $44.10 \pm 14.24$ (range 25.60-68.63) months. At the latest follow-up, mean postoperative VAS score for pain was $2.71 \pm 3.40$ and DASH score was $10.48 \pm 10.54$. Patients returned to work in $5.00 \pm 3.15$ months. Strength and Range of Motion (ROM) parameters were $\sim 80 \%$ of the contralateral side, with exception for extension (61\%) and radial deviation (73\%). After 2 years of follow-up, radiographic arthrosis was observed in $29 \%$ of the cases. One of these patients was symptomatic and was proposed for arthrodesis. Mean carpal height was $1.51 \pm 0.81$ and scapholunate angle was $41.58 \pm 22.82^{\circ}$. A correlation was observed between arthritis found at final followup and grip $(r=-0.8660 ; p<0.001)$ and pinch strength $(r=-0.8885 ; p<0.001)$. In conclusion, despite characteristic guarded prognosis, efforts to perform a prompt and adequate treatment are helpful. Clinical and radiological outcomes may not be related. Thus, it is of main importance to understand patients' perception of their sequelae.

Las lesiones perilunares son lesiones complejas y raras con afectación circunferencial de los huesos del carpo, ligamentos y cartílagos. A pesar del tratamiento quirúrgico óptimo, se espera un mal pronóstico y generalmente empeora con el tiempo. Nuestro objetivo fue abordar la clínica y radiología después de 2 años de seguimiento. Se revisaron 7 muñecas con una edad promedia de $35.59 \pm 14.10$ (rango 21-56) años y un seguimiento medio de $44.10 \pm 14.24$ (rango 25.60 - 68.63) meses. En el último seguimiento, la puntuación media de VAS postoperatoria para el dolor fue de $2.71 \pm 3.40$ y la puntuación DASH fue de $10.48 \pm 10.54$. Los pacientes volvieron al received

May 31, 2020

accepted

December 9, 2020
DOI https://doi.org/ 10.1055/s-0041-1729999. ISSN 1698-8396. (c) 2021. SECMA Foundation. All rights reserved.

This is an open access article published by Thieme under the terms of the Creative Commons Attribution-NonDerivative-NonCommercial-License, permitting copying and reproduction so long as the original work is given appropriate credit. Contents may not be used for commercial purposes, or adapted, remixed, transformed or built upon. (https://creativecommons.org/ licenses/by-nc-nd/4.0/)

Thieme Revinter Publicações Ltda., Rua do Matoso 170, Rio de Janeiro, RJ, CEP 20270-135, Brazil 


$\begin{array}{ll}\text { trabajo en } 5.00 \pm 3.15 \text { meses. Los parámetros de fuerza y movilidad estaban alrededor } \\ \text { de la barrera del } 80 \% \text { del lado contralateral, con excepción de la extensión }(61 \%) \text { y la } \\ \text { desviación radial }(73 \%) \text {. Después de } 2 \text { años de seguimiento, se observó artrosis } \\ \text { radiográfica en el } 29 \% \text { de los casos. Uno de estos pacientes era sintomático y fue } \\ \text { propuesto para artrodesis. La altura media del carpo fue de } 1.51 \pm 0.81 \text { y el ángulo } \\ \text { escafolunar fue de } 41.58 \pm 22.82 \text {. Se observó una correlación entre la artritis encon- } \\ \text { trada en el seguimiento final y la fuerza de agarre }(r=-0.8660 ; p<0.001) \text { y fuerza de } \\ \text { pellizco }(r=-0.8885 ; p<0.001), \text { pero no para el resto de parámetros clínicos y } \\ \text { Palabras clave } & \text { funcionales. En conclusión, a pesar del pronóstico cauteloso característico, los } \\ \text { - luxación } & \text { esfuerzos para realizar un tratamiento rápido y adecuado son útiles. Los resultados } \\ \text { - fractura-luxación } & \text { clínicos y radiológicos pueden no estar relacionados. Por lo tanto, es de vital } \\ \text { - artritis } & \text { importancia comprender la percepción de los pacientes de sus secuelas. }\end{array}$

\section{Introduction}

Perilunate injuries were first described by Joseph Francois Malgaigne $^{1}$ and pose as a type of carpal instability complex. ${ }^{2}$ In 1980, Mayfield staged a series of experiments into a new classification system: a continuum of four stages, ${ }^{3}$ in which progressive ligament and bone dissociation occur. ${ }^{2}$ Starting radially from the scaphoid, force propagates to the midcarpal and then ulnar aspects of the wrist, ${ }^{4}$ as the capitate and remainder of the carpus dislocate around the lunate. ${ }^{1}$ Scapholunate, radioscaphocapitate, lunotriquetal, dorsal intercarpal and radial colateral ligaments are torn and lunocapitate articulation is disrupted. ${ }^{4}$ Lunate dislocates from the lunate fossa of the distal radius ${ }^{1}$ after rotating out and around the short radiolunate ligament as an hinge. ${ }^{1}$ Reverse pattern of Mayfield classical injury has also been described. ${ }^{2}$ Herzberg further divided stages into two: stage I, when lunate remains in its place under the radius, and stage II, when lunate is palmarly dislocated from the radial fossa. ${ }^{2}$ At the end, according to Johnson, both pure ligamentous injuries around the lunate (lesser arc injuries) and fracture-dislocations involving bones around the lunate (greater arc injuries) can occur. ${ }^{5}$

Perilunate dislocations and fracture-dislocations affect mostly males ${ }^{6}$ after high energy trauma with wrist hyperextension ${ }^{1}$ and result in a swollen wrist with painful range of motion. ${ }^{1}$ Acute carpal tunnel syndrome may arise with a known incidence between $16 \%$ and $46 \%{ }^{2}$ Dislocation is frequently dorsal (95\% to $97 \%$ of the cases), ${ }^{1}$ but deformity can be subtle and spontaneous reduction has been reported. ${ }^{2}$ Up to $25 \%$ of the lesions are missed. ${ }^{1}$

Perilunate injuries are extremely complex with bone, ligamentous, capsule and cartilage involvement. ${ }^{7}$ Immediate treatment regards closed reduction with Tavernier maneuver and immobilization with a splint in neutral position. ${ }^{1}$ This gesture solves around $90 \%$ of median nerve related symptoms ${ }^{1}$ and achieve stable reduction in most of the cases. ${ }^{8}$ As definitive treatment, open anatomic reduction with fixation of fractures and ligamentous repair is usually advised for Mayfield stages I to III, ${ }^{4,7}$ with a growing role for arthroscopic techniques. ${ }^{9-11}$ Authors are frequently divided when referring to the best approach (dorsal alone $e^{1,4}$ or a combination of dorsal and volar $^{12}$ ) and a multiplicity of different constructs on what concerns fractures fixation or ligamentous stabilization have been described. ${ }^{4,12-14}$ For Mayfield stage IV no standardized treatment exists. ${ }^{15}$

Due to rarity of these lesions (around 7\% of all trauma in carpus $^{4}$ ), literature is sparse ${ }^{7,15}$. Despite optimal treatment, guarded prognosis is thought to be common and outcomes seem to be worse over time. ${ }^{2,7}$ Pain, partial loss of wrist motion and grip strength should be expected. ${ }^{8}$ Our work aims to address clinical and radiological results in a series of patients submitted to open surgery using dorsal and combined approach after 2 years of follow-up.

\section{Materials and Methods}

Study Design We conducted a retrospective observational study in patients diagnosed with closed perilunate dislocations and fracture-dislocations that were submitted to surgery in our center between May 2012 and July 2016. Revision and approval by Ethical and Health Committee of Hospital de Braga, Braga, Portugal were obtained. Inclusion criteria were: patients between 18 and 65 years old at the time of the surgery, closed injuries, unilateral lesions, follow-up greater than 24 months after surgery, agreement to consent study engagement and awareness and cooperation to participate in physical examination. A total of 7 patients were revised. Clinical (postoperative pain, global hand function, wrist range of motion and grip and pinch strength) and radiological parameters (carpal height, scapholunate angle and presence of wrist arthritis) were evaluated.

Surgical Technique All the patients were operated under general anesthesia. A pneumatic tourniquet was used ( $250 \mathrm{~mm} \mathrm{Hg}$ of pressure). Patients were in supine position and the affected limb was disposed into a lateral table. The approach was decided by the senior surgeon in charge. For combined approach, volar incision was done first. A curved 2 to $3 \mathrm{~cm}$ incision was done as an extension of carpal tunnel syndrome approach in the line of the ulnar border of the 
Palmaris Longus (PL) tendon and following the line of the $4^{\text {rd }}$ ray. $P L$ tendon was radially retracted, volar carpal ligament was incised and decompression of median never was performed. By radially retracting the nerve and tendons, volar capsule and ligaments were inspected and sutured if needed. Dorsal approach was done with a 4 to $5 \mathrm{~cm}$ longitudinal and median centered incision, between Lister's tubercle and metacarpal bases. Extensor's retinaculum was incised between the $3^{\text {rd }}$ and $4^{\text {rd }}$ extensor compartments and tendons were retracted by using rubber loops. Neurectomy of posterior interosseous nerve (PIN) was done. Dorsal capsulotomy was performed according to Berger technique. ${ }^{16}$ Fractures were anatomically reduced and fixated with Herbert type screws. Joysticks were positioned to extend scaphoid and flex lunate when needed to correct dorsal or volar intercalated segment instability (DISI or VISI). In pure dislocations, both scapholunate (SL) and lunotriquetral (LT) intervals were pinned with 2 K-wires each. In fracture-dislocations involving scaphoid fracture, only LT interval was pinned. Slight modifications were made by the surgeon as needed. Ligaments' remnants were evaluated and reinsertion with anchors was made, unless they were absent. Skin was closed with non-absorbable sutures. A dorsal splint was applied in all the cases.

Postoperative Treatment K-wires were removed after 6 weeks. In the postoperative period, all the patients sustained 8 weeks of wrist immobilization. Physical rehabilitation was started afterwards. Total time of therapy was stated on an individual basis.

Outcome Measures The collection and analysis of all the data were done by an independent investigator. Clinical and radiological data were accessed at the final follow-up. Visual Analogue Scale (VAS) for pain (0 to 10 ) was applied and data from preoperative period were reviewed. Global hand function was evaluated using Disabilities of the Arm, Shoulder and Hand (DASH) questionnaire (0 to 100) validated for Portuguese population from. Wrist range of motion (ROM) parameters (extension, flexion, radial deviation, ulnar deviation, pronation and supination) were evaluated with classic goniometer. Grip strength $(\mathrm{N})$ and pinch strength $(\mathrm{N})$ were obtained by the mean of three repeated measures with dynamometer (Lafayette Hand-Held Dynamometer Model 01165, Lafayette, IN 47904, USA). Time to return to work and need for reintervention were accessed. Any postoperative complications were noted. Preoperative plain radiographs (front and lateral views) and Computed Tomography (CT) scans were used to confirm diagnosis and lesion classifications, according to Mayfield ${ }^{3}$ and Herzeberg. ${ }^{17}$ Postoperative plain radiographs (front and lateral views) were reviewed to access: carpal height using Nattrass method, ${ }^{18}$ scapholunate angle $\left({ }^{0}\right)$ and presence of wrist arthritis according to Watson. ${ }^{19}$

Statistical Analysis Quantitative variables are described as mean and standard deviation using Graph Pad Prism 8 for Windows 10. Results of ROM and strength are expressed in percentage of the contralateral limb function. Correlation between clinical results (ROM and strength) and radiological features (wrist arthrosis) was tested using Spearman rank correlation test with confidence interval of $95 \%$ and $p<0.05$.

\section{Results}

A total of 7 patients, all males, were revised. Mean age was $35.59 \pm 14.01$ (range 21-56) years old and mean follow-up was $44.10 \pm 14.24$ (range 25.60-68.63) months. Dominant side was specially affected. Most of the cases arose after motorcycle accident. Perilunate-fracture-dislocations occurred in the majority of the cases. The commonest fractured bone was the scaphoid, followed by radial styloid and hamate. Time until surgery was $7.29 \pm 14.94$ days by mean. One of the patients was not diagnosed in a first visit (14\%). Demographic features are displayed in - Table 1.

From 7 lesions, 5 were operated using combined approach and 2 with isolated dorsal approach. For the former, there was no need for subsequent lunate reduction, but volar capsular and ligamentous repair were done in 2 of them. Fractures were fixed using Herbert type screws. Transarticular pinning was done using K-wires. Ligaments were reinserted with anchors in 4 cases. In patients 4,5 and 7, ligamentous repair or reinsertion was not possible due to their friable state. No complications were noted. Surgical data are detailed in - Table 2.

At the latest follow-up, mean postoperative VAS score for pain was $2.71 \pm 3.40$. Average postoperative DASH score was $10,48 \pm 10.54$. Time to return to work was $5.00 \pm 3.15$ months by mean. One of the patients was not available to return to previous functions. These results are detailed in - Table 2. Mean values for strength and ROM are displayed in - Table 3.

After 2 years of follow-up, 2 out of 7 wrists developed arthrosis (29\%). One of these patients was symptomatic and was proposed for a 4-corner-arthrodesis (patient 3). The other was classified as asymptomatic Watson 1 arthritis. Radiological data are detailed in - Table 4.

A negative correlation was observed between arthritis at final follow-up and grip $(r=-0.8660 ; p<0.001)$ and pinch strength $(r=-0.8885 ; p<0.001)$. There was no correlation for all the other clinical and functional parameters.

\section{Discussion}

Perilunate dislocations and fracture-dislocations are extremely complex injuries that carry a guarded prognosis, even when the most adequate surgical treatment is performed. As a spectrum of a rare injury, multiple lesion patterns are expected and several options are available for their management. Anatomic reduction, fracture fixation and ligamentous repair are often required, but controversy still occurs among sparse literature. Our group describe clinical and radiological results after 2 years of surgical management of these lesions.

Our sample included 7 young male patients involved in high energy trauma. Lesions involving fractures were dominant and the most fractured bone was scaphoid. These demographics are concurrent with epidemiologic data described in previous papers. ${ }^{1,6}$ Percentage of misdiagnosis was however slightly below the $25 \%$ standard threshold. ${ }^{1}$

In most of our patients, a combined approach was used. Controversy regarding the gold-standard approach spikes 
Table 1 Demographic features

\begin{tabular}{|c|c|c|}
\hline & \multicolumn{2}{|l|}{$n$} \\
\hline Patients included & \multicolumn{2}{|l|}{7} \\
\hline Male patients & \multicolumn{2}{|l|}{7} \\
\hline Female patients & \multicolumn{2}{|l|}{0} \\
\hline Undiagnosis & \multicolumn{2}{|l|}{1} \\
\hline Dominant side affected & \multicolumn{2}{|l|}{5} \\
\hline \multicolumn{3}{|l|}{ Mechanism of Lesion } \\
\hline Motorcyle accident & \multicolumn{2}{|l|}{4} \\
\hline Fall from heigh & \multicolumn{2}{|l|}{1} \\
\hline Sports accident & \multicolumn{2}{|l|}{1} \\
\hline Work-related & \multicolumn{2}{|l|}{1} \\
\hline Perilunate dislocation & \multicolumn{2}{|l|}{2} \\
\hline Perilunate-fracture-dislocation & \multicolumn{2}{|l|}{5} \\
\hline Scaphoid & \multicolumn{2}{|l|}{4} \\
\hline Radial Styloid & \multicolumn{2}{|l|}{2} \\
\hline Hamate & \multicolumn{2}{|l|}{1} \\
\hline Triquetral & \multicolumn{2}{|l|}{1} \\
\hline \multicolumn{3}{|l|}{ Mayfield Classification } \\
\hline Stage 1 & \multicolumn{2}{|l|}{1} \\
\hline Stage 2 & \multicolumn{2}{|l|}{0} \\
\hline Stage 3 & \multicolumn{2}{|l|}{3} \\
\hline Stage 4 & \multicolumn{2}{|l|}{3} \\
\hline \multicolumn{3}{|l|}{ Herzberg Classification } \\
\hline Grade I & \multicolumn{2}{|l|}{4} \\
\hline Grade IIA & \multicolumn{2}{|l|}{3} \\
\hline \multirow[t]{2}{*}{ Grade IIB } & \multicolumn{2}{|l|}{0} \\
\hline & Mean & Sd \\
\hline Age (years old) & 35.59 & 14.10 \\
\hline Follow-up (months) & 44.10 & 14.24 \\
\hline Time until surgery (days) & 7.29 & 14.97 \\
\hline
\end{tabular}

Abreviation: Sd, standard deviation.

the literature. Many authors state dorsal approach as preferential, as it allows both anatomic fixation of carpal fractures and dorsal ligamentous repair, which are key factors for a successful outcome.,4 Other authors claim combined approach is preferred for these circumferential injuries. ${ }^{12}$ In fact, by adding a volar incision, the surgeon is able not only to reduce the lunate when it appears still dislocated, but also to perform direct repair of the capsule tear on the space of Poirier. ${ }^{1,4,12}$ However, additional swelling, difficulties with wound closure and slower recovery of digital flexion are mentioned. $^{12}$ In our center, approach is decided by the responsible surgeon for treatment. Taken this fact in mind and knowing the small size of our sample, unfortunately we are not able to perform a statistical comparison of clinical and radiological results between one option or another. Either way, it is important to emphasized that no complications were noted regarding specifically the approach.
Fractures were fixed using Herbert type screws in all the cases. Most authors advice internal fixation with headless compression or cannulated screws, although K-wire fixation has also been used successfully in smaller or comminuted factures. ${ }^{9}$ Ligamentous injuries should undergo primary repair or reinsertion to avoid VISI or DISI. ${ }^{1,2,8}$ From 7 wrists, 4 were submitted to ligamentous reinsertion. In the remaining 3, ligaments were too friable to be repaired or reinserted. Repair is thought to confer better outcomes, but this has not been objectively examined in literature. ${ }^{2}$ Transarticular pinning was done in all the cases using K-wires. In previous literature, comparable results between intercarpal K-wires and screws were obtained with the need for subsequent removal as a drawback for screw fixation. ${ }^{12}$ Typical disadvantages related to K-wires, such as pin tract infection or soft-tissue irritation, ${ }^{8}$ were not reported on our series.

Our first aim was to describe clinical and functional results after 2 years of follow-up of surgical treatment. Mean postoperative VAS score for pain was $2.71 \pm 3.40$, overlapping literature. ${ }^{20}$ However, pain is expected in $20-30 \%$ of the patients ${ }^{7}$ and it is important to note that two of our cases had a VAS score between 7 and 8 points (patient 2 and 6). Mean postoperative DASH score was $10.48 \pm 10.54$. This is quite a low value when comparing to literature (reference values between 23 and 27). ${ }^{10,20}$ Time to return to work was 5.00 months by mean. One of our patients was not able to resume previous job, as he was a heavy manual worker. These are, however, acceptable results when considering the poor prognosis of these kind of injuries.

In general, grip and pinch strength were $82 \%$ and $91 \%$ of the contralateral side, respectively. These results are slightly higher than the ones reported in literature, ${ }^{20}$ in the same line with patients' perception of their status (DASH score of 10.48). ROM parameters were around the $80 \%$ barrier of the contralateral side. Exceptions were extension (around 61\%) and radial deviation (73\%). In a study involving 39 operated patients with an average of 65,5 months of follow-up, Kremer observed ROM of $63 \%$ and $61 \%$ of contralateral side for extension/flexion and radial/ulnar deviation. Our data concur with these achievements. Global and significant loss of extension might be related to the complexity of the lesion itself: capsular and ligamentous involvement rise the probability of dorsal contracture and the risk for significant sequelae. We have not enough data though to conclude whether this feature can worse the results in our series.

At the final follow-up, percentage of arthritis was $29 \%$. This is a reasonable value for our period of follow-up, but we expect a worsening with time, according to previous papers. $^{7,20}$ Only one of the two cases was symptomatic and was proposed for arthrodesis. However, a correlation between presence of arthritis and decrease of grip and pinch strength was found $(r=-0.8660 ; p<0.001$ and $r=-0.8885$; $p<0.001$, respectively). VAS and DASH scores were not related to arthritis. From our data, we conclude that presence of arthritis does not lead predictably to wrist pain or poor patients' subjective outcome, as stated previously. ${ }^{1,4}$ However, reduced function can really occur, although well 
Table 2 Clinical results in detail

\begin{tabular}{|c|c|c|c|c|c|c|}
\hline & \multirow[t]{2}{*}{ Diagnosis } & \multirow[t]{2}{*}{ Approach } & \multirow[t]{2}{*}{ Surgery } & VAS & \multirow{2}{*}{$\begin{array}{l}\text { DASH } \\
(0-100)\end{array}$} & \multirow{2}{*}{$\begin{array}{l}\text { Time to } \\
\text { return to } \\
\text { work } \\
\text { (months) }\end{array}$} \\
\hline & & & & $(0-10)$ & & \\
\hline Patient 1 & $\begin{array}{l}\text { Transtriquetral-perilunate-frac- } \\
\text { ture-dislocation }\end{array}$ & $\begin{array}{l}\text { Volar and } \\
\text { Dorsal }\end{array}$ & $\begin{array}{l}\text { Median nerve decompression; SL, LT } \\
\text { and LC fixation; SL and LT ligaments } \\
\text { reinsertion }\end{array}$ & 0 & 1.67 & 2.00 \\
\hline Patient 2 & $\begin{array}{l}\text { Transcapho-transcapitate- } \\
\text { transhamate-perilunate-frac- } \\
\text { ture-dislocation }\end{array}$ & Dorsal & $\begin{array}{l}\text { Scaphoid and capitate fixation; trans- } \\
\text { articular fixation not done; SL and LT } \\
\text { ligaments intact }\end{array}$ & 7 & 5.83 & 6.00 \\
\hline Patient 3 & $\begin{array}{l}\text { Transradial-transcapho-perilu- } \\
\text { nate-fracture-dislocation }\end{array}$ & $\begin{array}{l}\text { Volar and } \\
\text { Dorsal }\end{array}$ & $\begin{array}{l}\text { Median nerve decompression and volar } \\
\text { capsule and RSC ligament suture; radial } \\
\text { styloid and scaphoid fixation; LT fixa- } \\
\text { tion; LT ligament reinsertion; SL liga- } \\
\text { ment intact }\end{array}$ & 2 & 28.33 & 8.00 \\
\hline Patient 4 & $\begin{array}{l}\text { Transcapho-perilunate-frac- } \\
\text { ture-dislocation }\end{array}$ & Dorsal & $\begin{array}{l}\text { Scaphoid fixation; SL and LT fixation; SL } \\
\text { ligament reinsertion; LT ligament repair } \\
\text { not possible }\end{array}$ & 0 & 0.00 & 4.00 \\
\hline Patient 5 & Perilunate dislocation & $\begin{array}{l}\text { Volar and } \\
\text { Dorsal }\end{array}$ & $\begin{array}{l}\text { Median nerve decompression; SL and LT } \\
\text { fixation; SL and LT ligaments repair not } \\
\text { possible }\end{array}$ & 2 & 13.33 & - \\
\hline Patient 6 & $\begin{array}{l}\text { Transradial-transcapho-perilu- } \\
\text { nate-fracture-dislocation }\end{array}$ & $\begin{array}{l}\text { Volar and } \\
\text { Dorsal }\end{array}$ & $\begin{array}{l}\text { Median nerve decompression; radial } \\
\text { styloid and scaphoid fixation; LT fixa- } \\
\text { tion; LT ligament reinsertion; SL liga- } \\
\text { ment intact }\end{array}$ & 8 & 20.00 & 2.00 \\
\hline Patient 7 & Perilunate dislocation & $\begin{array}{l}\text { Volar and } \\
\text { Dorsal }\end{array}$ & $\begin{array}{l}\text { Median nerve decompression and volar } \\
\text { capsule and volar LT ligament suture; SL } \\
\text { and LT fixation; SL ligament repair not } \\
\text { possible }\end{array}$ & 0 & 4.17 & 800 \\
\hline Mean & - & - & - & 2.71 & 10.48 & 5.00 \\
\hline Sd & - & - & - & 3.40 & 10.54 & 3.15 \\
\hline
\end{tabular}

Abreviations: DASH, Disabilities of the Arm, Shoulder and Hand; LC, lunocapitate; LT, lunotriquetral; RSC, radioscaphocapitate; Sd, standard deviation; SL, scapholunate; VAS, Visual Analogue Scale for Pain in postoperative period.

Table 3 Results of functional parameters

\begin{tabular}{|c|c|c|c|c|c|c|c|c|}
\hline & \multicolumn{2}{|c|}{ Grip Strenght (N) } & \multicolumn{2}{|c|}{ Pinch Strenght (N) } & \multicolumn{2}{|c|}{ Extension $\left({ }^{\circ}\right)$} & \multicolumn{2}{|c|}{ Flexion $\left({ }^{0}\right)$} \\
\hline & Mean & $S d$ & Mean & Sd & Mean & $S d$ & Mean & $S d$ \\
\hline Op. Side & 163.1 & 65.85 & 63.82 & 27.85 & 29.71 & 13.19 & 50.00 & 11.55 \\
\hline Ct. Side & 193.16 & 53.30 & 73.84 & 23.34 & 49.71 & 14.16 & 62.29 & 17.07 \\
\hline \multirow[t]{3}{*}{ \% Op. Side } & 82 & 17 & 91 & 27 & 61 & 27 & 90 & 51 \\
\hline & \multicolumn{2}{|c|}{ Radial Deviation $\left({ }^{\circ}\right)$} & \multicolumn{2}{|c|}{ Ulnar Deviation $\left({ }^{0}\right)$} & \multicolumn{2}{|c|}{ Pronation $\left({ }^{0}\right)$} & \multicolumn{2}{|c|}{ Supination $\left({ }^{0}\right)$} \\
\hline & Mean & $S d$ & Mean & Sd & Mean & $S d$ & Mean & Sd \\
\hline Op. Side & 15.71 & 7.34 & 20.57 & 8.06 & 71.14 & 24.24 & 59.00 & 28.24 \\
\hline Ct. Side & 22.86 & 5.87 & 28.29 & 8.60 & 70.00 & 23.52 & 74.57 & 21.16 \\
\hline \% Op. Side & 73 & 35 & 78 & 36 & 102 & 12 & 80 & 32 \\
\hline
\end{tabular}

Abreviations: Ct., Contralateral; N, Newtons; Op., Operated; Sd, Standard deviation.

tolerated. Carpal height and scapholunate angle were not related to clinical and functional outcomes.

Our study has some important limitations. First of all, our sample is very small (only 7 subjects). A short sample size not only limits the overlapping of the conclusions to general population, but can also compromise the validity of our statistical correlations. Taken these facts, the present work still highlights the description of treatment and results of a very rare lesion. Endorsing a prospective study with larger sample and longer follow-up should be valuable in a near future. Second, grip strength radiographs were not available for the majority the patients, as they were asked only for symptomatic patients. Data regarding scapholunate gap were not included for this reason. Nevertheless, it's important to bear in mind that it is an important measure to be counted on. 
Table 4 Results of radiological parameters

\begin{tabular}{|l|l|l|}
\hline & Carpal Height & $\begin{array}{l}\text { Scapholunate } \\
\text { angle }\left(^{(}\right)\end{array}$ \\
\hline Mean & 1.51 & 41.58 \\
\hline Sd & 0.81 & 22.82 \\
\hline & Wrist Arthritis & Reintervention \\
\hline$n$ & 2 & 1 \\
\hline Description & $\begin{array}{l}\text { Watson 1; } \\
\text { Watson 3 }\end{array}$ & $\begin{array}{l}\text { 4-corner } \\
\text { arthrodesis }\end{array}$ \\
\hline
\end{tabular}

Abreviation: Sd, standard deviation.

${ }^{*}$ Carpal Height according to Natrass method.

${ }^{* *}$ Wrist arthosis using Watson classification.

\section{Conclusion}

In conclusion, perilunate injuries are very complex lesions which characteristically have a guarded prognosis. Loss of function is expected, but efforts to perform a prompt and adequate treatment are helpful to avoid worst results. As clinical and radiological outcomes are not imperatively related, it is important to percept how patients are dealing with their sequelae behind the radiographs to decide when to escalate treatment options.

\section{Disclosures}

All the authors state no conflicts of interest.

\section{References}

1 Kardashian G, Christoforou DC, Lee SK. Perilunate dislocations. Bull NYU Hosp Jt Dis 2011;69(01):87-96

2 Sawardeker PJ, Kindt KE, Baratz ME. Fracture-dislocations of the carpus: perilunate injury. Orthop Clin North Am 2013;44(01):93-106

3 Mayfield JK, Johnson RP, Kilcoyne RK. Carpal dislocations: pathomechanics and progressive perilunar instability. J Hand Surg Am 1980;5(03):226-241

4 Muppavarapu RC, Capo JT. Perilunate Dislocations and Fracture Dislocations. Hand Clin 2015;31(03):399-408
5 Johnson RP. The acutely injured wrist and its residuals. Clin Orthop Relat Res 1980;(149):33-44

6 Kohli S, Khanna V, D Virani N,Chaturvedi H. Transradial, Transscaphoid, Transcapitate, Perilunate Dislocation; A Case Report and Approach to the Patient. Bull Emerg Trauma 2016;4(01): 54-57

7 Israel D, Delclaux S, André A, et al. Peri-lunate dislocation and fracture-dislocation of the wrist: Retrospective evaluation of 65 cases. Orthop Traumatol Surg Res 2016;102(03):351-355

8 Stanbury SJ, Elfar JC. Perilunate dislocation and perilunate fracture-dislocation. J Am Acad Orthop Surg 2011;19(09):554-562

9 Jones DB Jr, Kakar S. Perilunate dislocations and fracture dislocations. J Hand Surg Am 2012;37(10):2168-2173, quiz 2174

10 Muller T, Hidalgo Diaz JJ, Pire E, Prunières G, Facca S, Liverneaux P. Treatment of acute perilunate dislocations: ORIF versus proximal row carpectomy. Orthop Traumatol Surg Res 2017;103(01):95-99

11 Kim JP, Lee JS, Park MJ. Arthroscopic treatment of perilunate dislocations and fracture dislocations. J Wrist Surg 2015;4(02): 81-87

12 Montero Lopez NM, Paksima N. Perilunate Injuries and Dislocations Etiology, Diagnosis, and Management. Bull Hosp Jt Dis (2013) 2018;76(01):33-37

13 Kara A, Celik H, Seker A, Kilinc E, Camur S, Uzun M. Surgical treatment of dorsal perilunate fracture-dislocations and prognostic factors. Int J Surg 2015;24(Pt A):57-63

14 Grabow RJ, Catalano L III. Carpal dislocations. Hand Clin 2006;22 (04):485-500, abstract vi-vii

15 Arango D, Tiedeken NC, Ayzenberg M, Raphael J. Open perilunate injury with lunate revascularization after complete ligamentous avulsion. J Surg Case Rep 2014;2014(05):rju041

16 Berger RA. A method of defining palpable landmarks for the ligament-splitting dorsal wrist capsulotomy. J Hand Surg Am 2007;32(08):1291-1295

17 Herzberg G, Comtet JJ, Linscheid RL, Amadio PC, Cooney WP, Stalder J. Perilunate dislocations and fracture-dislocations: a multicenter study. J Hand Surg Am 1993;18(05):768-779

18 Nattrass GR, King GJ, McMurtry RY, Brant RF. An alternative method for determination of the carpal height ratio. J Bone Joint Surg Am 1994;76(01):88-94

19 Watson HK, Ballet FL. The SLAC wrist: scapholunate advanced collapse pattern of degenerative arthritis. J Hand Surg Am 1984;9 (03):358-365

20 Kremer T, Wendt M, Riedel K, Sauerbier M, Germann G, Bickert B. Open reduction for perilunate injuries-clinical outcome and patient satisfaction. J Hand Surg Am 2010;35(10):1599-1606 